then a general discussion of Franklin's own place in the current of Newtonian science. In the last and longest part we are given a detailed account of the investigations into electricity in the eighteenth century, in which Franklin played a central part, and the book ends with a bibliography of nearly fifty pages and an index.

In spite of the excellence of the individual sections of the work, which are written. with the authority of one who already has many contributions in the field to his credit, it is doubtful whether the somewhat disjointed thesis is adequate for so massive a work. The author himself recognizes that individual readers may wish to study only parts of the book, and he provides a detailed table of contents expressly for their convenience. But in spite of this defect in the work as a whole, the full and careful treatment which the individual topics receive will earn for Prof. Cohen the gratitude of all whose interests lie in this field.

M. A. Hoskin

\section{BRUNONIAN DOCTRINE IN MEXICO}

\section{El Brownismo en México}

Un estudio critico, seguido de la primera edición de la version castellana que hizo en México hacia 1800, el Doctor Don Luis José Montaña, de los "Elementos de Medicina" del Dr. Juan Brown. (Cultura Mexicana, No. 14.) Pp. ii 311. (México : Imprenta Universitaria, 1956.) n.p.

$\mathrm{D}$ R. J. J. IZQUIERDO, who is professor of physiology in the University of Mexico and a well-known historian of medicine, has edited the Spanish translation of John Brown's "Elementa Medicinae" (1780) from a manuscript written about 1800 by Luis Jose Montaña (1755-1820), one of the most distinguished pioneers of medical teaching in Mexico. As a preface to the translation, Dr. Izquierdo contributes an interesting essay entitled "El Brownismo on México", which is also the title of the book.

It is a little difficult to understand why the author, who has already performed such useful service by editing Montaña's commentary on the Hippocratic works under the title "El Hipocratismo en México" (1955), should now regard Brown's treatise as worthy of similar attention. The "Elementa Medicinae" is by no means a medical classic. It was never taken seriously in Great Britain, and almost every medical historian, whether in Britain or abroad, regards Brown as a figure for derision and not for praise. Nevertheless, although in his own day he was a mere charlatan in the eyes of most of his colleagues, Brown was highly esteemed by many of his students and patients, and was well known on the Continent, especially in Germany, where, at the University of Gotttingen, a riot between the rival factions concerning his doctrine was quelled only by military

John Brown, a schoolmaster of Duns, Berwickshire, who turned his attention to medicine and was a graduate of St. Andrews and a student at Leyden, became a pupil and secretary in the house of the famous William Cullen of Edinburgh, and at a later stage the bitter opponent and rival of the patron to whom he owed so much. Brown has been fitly called the Paracelsus of Scotland, since he was regarded by some as a genius and by others as a complete charlatan. The 'system', to which he laid claim as his own although it dated from the time of Asclepiades, was ridiculous in its simplicity. In his view health, and even life itself, was a response to continuous stimula. tion by warmth, food, fresh air, etc. When the stimuli were withdrawn, death resulted. Disease was caused either by excess or by diminution of stimulation. Consequently there were only two kinds of diseases, the sthenic, caused by too much stimulation, and the asthenic, caused by two little, or by depressive factors. Treatment consisted of the use of sedatives (usually opium) for the former, and of stimulants (preferably alcohol) for the latter. Such a simple and easy scheme of medical practice could not fail to attract the attention of physicians of that time, many of whom were perplexed and bewildered by the complexities of iatro-physics and iatro-chemistry, the twin theories which viewed the human body as a machine or a test-tube, and which had been introduced in place of the age-long theory of the 'humours'. 'Brownism', demanding little study or thought, appealed strongly also to students who welcomed relief from the burden of examinations. But there was a redeeming feature of the new system. Perhaps Brown, in spite of all his failings and fallacies, did actually perform a useful service in directing attention to the importance of the biological, as opposed to the physico-chemical, aspect of medicine. His doctrine may have formed a bridge, however frail and slender, between the scholastic age and the age of medical science.

Accordingly, we need not be surprised to learn that Brownism exercised some beneficial influence upon medical education in Mexico, a progressive country which could lay claim to the first hospital (1523) and the first organized medical teaching (1580) in. the American continent, as well as to the first medical journal of the western world (Mercurio Volante, 1772). It does seem strange that Brown's "Elementa Medicinae" was translated into Spanish only twenty years after it was written, while Harvey's "De Motu Cordis" appeared in a Spanish version only after a lapse of more than three hundred years (1936). The reason was that Brown's work, at the time of its appearance, seemed to offer an easy solution to nearly every problem in medical practice, whereas Harvey's treatise, though infinitely more significant, remained misunderstood and devoid of practical outcome for many years. It was, in fact, born far ahead of its time, whereas Brown's answer to a pressing need was eagerly grasped and widely applied as soon as it appeared.

Dr. Izquierdo has therefore been fully justified in adding this curious chapter to his former studies of the early progress of medical education in Mexico. We are too apt to forget that the early history of medicine in Latin America had important repercus. sions throughout the civilized world and that it is a subject well worthy of our attention. The present volume is a fitting sequel to the author's splendid work on "Monteña y los origines del movimiento socially cientifico de México", and a fine tribute to the ancient medical school. It also serves to remind us that the phenomenon of the 'Brunonian System', or as the writer calls it, 'Brownism', despite its absurd simplicity, helped to divert medical thought, in Mexico and elsewhere, away from the traditional and often sterile theories, and towards the beginnings of the scientific basis which lies at the root of all real progress in modern medicine.
Dodglas GUTHRIE 